\title{
Implementasi Internet of Things Pada Alat Penimbangan Muatan Truk Berbasis RFID
}

\author{
Alpha Rabbi Sugara, Ahmad Taqwa, Abdul Rakhman \\ Fakultas Teknik Elektro, Teknik Telekomunikasi, Politeknik Negeri Sriwijaya, Palembang, Indonesia \\ Jl.Srijaya Negara, Bukit Lama, Kec. Ilir Barat I, Kota Palembang 30139 \\ alpharabbys@gmail.com, Tommy@polsri.ac.id, abdulrakhman@gmail.com
}

\begin{abstract}
In the world of transportation, weigh bridges have important funding for freight transport fleets, one of which is trucks. The higher the distribution of goods that occur, the more trucks that exceed the maximum load circulate on the highway.. Control of truck load control at weigh bridges is still not optimal because it is still recording cargo manually. As a result, traffic jams and illegal collections often occur around weigh stations. From the above problems, a tool that can automatically load RFID-based trucks using a load cell sensor is made, the process of paying truck loads that exceeds the maximum load using E-Money and the weighing data of trucks will be sent directly to government stakeholders using the Internet method of Things (IoT) in order to make it easier for officers at weigh stations to do work. This weighing device uses a Raspberry pi microcontroller as a sensor controller and RFID as a truck detector.
\end{abstract}

Keywords: Load Cell, Internet of Things, RFID, E- Money, Raspberry pi

Abstrak
Dalam dunia transportasi, jembatan timbang mempunyai peranaan penting bagi armada angkutan barang, salah satunya adalah truk. Semakin tinggi distribusi barang yang terjadi, semakin banyak truk - truk yang melebihi beban maksimum beredar dijalan raya. Pengawasan kontrol muatan truk pada jembatan timbang masih kurang optimal karena masih melakukan pencatatan muatan secara manual.akibatnya sering terjadi kemacetan dan pungli disekitar jembatan timbang. Dari permasalahan diatas, maka dibuatlah suatu alat yang dapat menimbang muatan truk secara otomatis berbasis RFID menggunakan sensor load cell, proses pembayaran muatan truk yang melebihi beban maksimum menggunakan E- Money dan data hasil penimbangan muatan truk akan dikirim langsung ke web stakeholder pemerintah menggunakan metode Internet of Things (IoT) agar dapat mempermudah petugas di jembatan timbang dalam melakukan pekerjaan. Alat penimbangan ini menggunakan mikrokontroller Raspberry pi sebagai pengendali sensor dan RFID sebagai pendeteksi truk.

Kata kunci: Sensor Berat, Internet of Things, RFID, E- Money, Raspberry pi

\section{PENDAHULUAN}

Dengan berkembangnya teknologi saat ini, berbagai alat elektronika yang bertujuan untuk mempermudah dan mengefektifkan waktu serta kerja manusia yang terus bermunculan. Munculnya alat-alat ini sangat berperan penting dalam era modernisasi, dimana alat ini dapat dijumpai dikehidupan manusia setiap harinya. Semakin berkembangnya teknologi sekarang maka semakin berkembang juga pola pikir manusia, manusia berusaha mencari solusi yang tepat agar dapat 
mempermudah menjalani kehidupannya dan memiliki keinginan semua kebutuhannya dapat dilakukan dengan cepat dan praktis tanpa harus membuang waktu. Salah satu usaha untuk memberikan kemudahan dan kenyamanan tersebut adalah alat penimbangan otomatis serta pengiriman data hasil timbangan menggunakan Internet of Things (IoT)[1].

Di dalam dunia transportasi, jalan raya merupakan suatu fasilitas penting untuk kendaraan berjalan, dimana jalan memiliki bobot maksimal sehingga untuk mengurangi resiko kerusakan jalan dibuatkan alat timbang untuk mengetahui kendaraan yang melebihi batas bobot jalan raya. Semakin tingginya distribusi barang dari satu tempat ke tempat lain menyebabkan banyak armada angkutan barang yang mengangkut muatan melebihi beban tonase yang diizinkan. Akibatnya pengawasan kontrol muatan angkutan barang pada jembatan timbang kurang optimal karena masih melakukan pencatatan muatan secara manual. Pencatatan secara manual ini berdampak pada kemacetan yang panjang di sekitar jembatan timbang, sehingga mengganggu lalu lintas, pemalsuan data yang mendorong adanya pugutan liar, dan mengakibatkan jalanan cepat rusak karena jalan yang dilewati oleh truk-truk tersebut tidak sesuai standar.

Truk-truk yang memiliki muatan berlebih juga mengakibatkan jalanan cepat rusak karena jalan yang dilewati oleh truk-truk tersebut tidak sesuai standar. Menurut hasil survei The Asia Fundation, truk-truk yang beroperasi sepanjang sembilan rute survei pada umumnya kelebihan muat sebesar $45 \%$, atau 4 ton di atas berat beban maksimal yang mendapatkan izin dari pihak jembatan timbang. Tidak hanya itu, pungutan liar juga terjadi di jembatan timbang dengan data sebesar $22 \%$ biaya total transportasi yang dikeluarkan oleh supir truk merupakan pungutan liar[2].

Akibat dari tiga permasalahan jembatan timbang ini, pada tanggal 1 Januari 2017 pengelolaan Jembatan Timbang yang mulanya ditangani oleh Pemerintah Daerah beralih ke Pemerintah Pusat yaitu Kementerian Perhubungan. Jembatan timbang di Indonesia mulai beroperasi pada 21 April 2017. Pengoperasian kembali ini hanya pada 25 jembatan timbang di Indonesia dan belum beroperasi secara maksimal sampai saat ini.

\section{METODOLOGI PENELITIAN}

Langkah awal yang harus dilakukan adalah mempersiapkan semua data-data yang diperlukan untuk memulai membuat alat. Kemudian dilanjutkan dengan membuat desain dari sistem yang akan dibuat seperti blok diagram, desain layout/aplikasi, flowchart, cara kerja, proses pembuatan alat serta menentukan kebutuhan yang akan digunakan. Jika suatu alat menggunakan perangkat lunak (software), maka langkah selanjutnya ialah melakukan penyetinggan software menggunakan koding-koding maupun perintah sesuai dengan desain yang akan dibuat. Setelah dilakukan pembuatan serta penyetinggan software, maka alat yang dibuat harus dites untuk mengetahui apakah program ataupun rangkaian yang dibuat sudah benar[3]. Jika alat tersebut sudah bekerja sesuai dengan yang 
diharapkan, maka langkah terakhir adalah mengimplementasikan langsung alat yang dibuat.

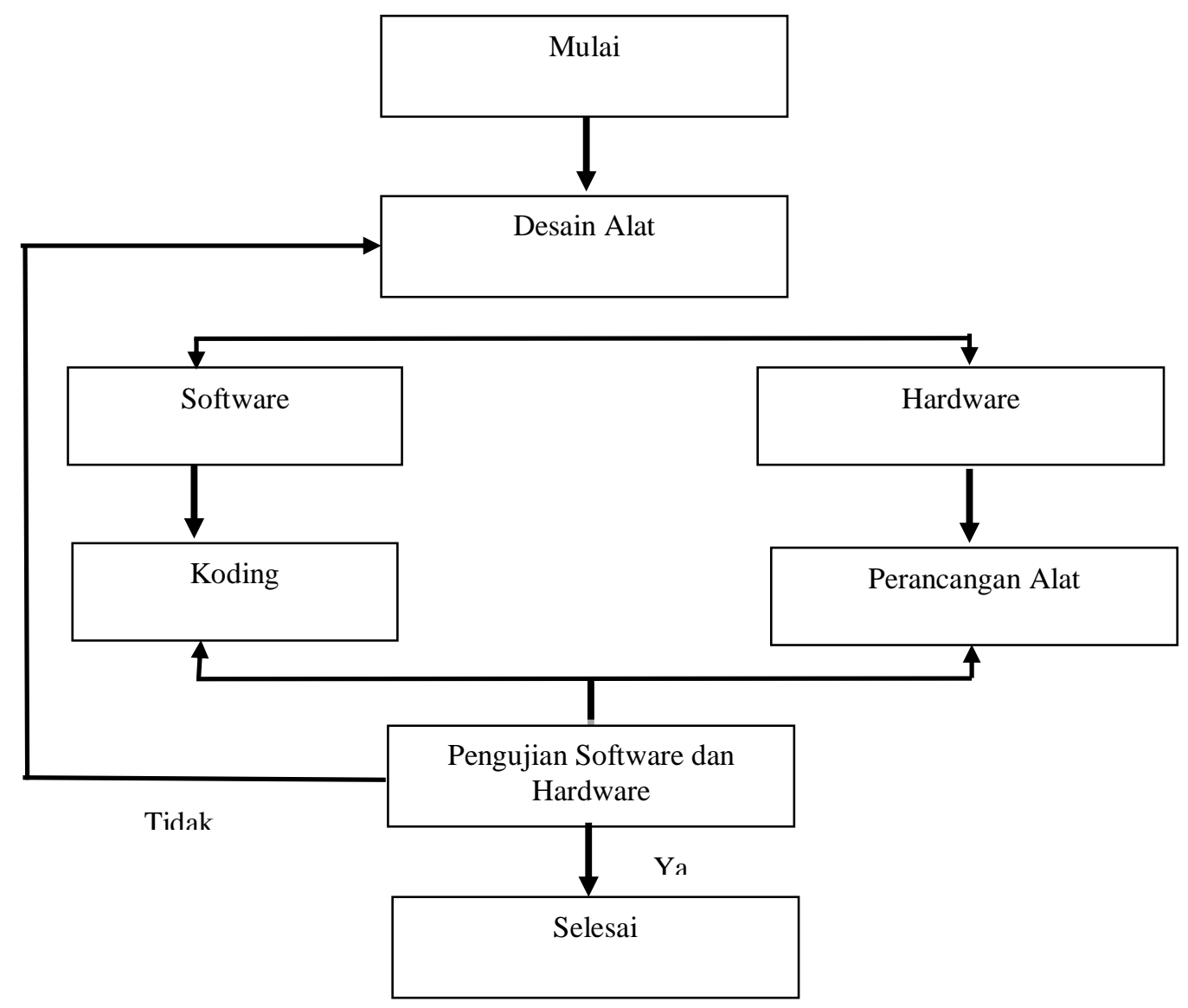

Gambar 1. Desain Sistem

\subsection{Perancangan Perangkat Keras}

Perancangan perangkat keras (hardware) yaitu alat yang akan dibuat diawali dengan pembuatan blok diagram sistem secara keseluruhan. Pada dasarnya alat ini dirancang untuk mempermudah petugas disekitar jembatan timbang dalam melakukan penimbangan muatan truk, dikarenakan semakin menigkatnya kesibukan maka setiap hal dituntut agar dapat dilakukan dengan cepat, tepat, dan praktis. Dan juga sebagai pengembangan sistem teknologi yang ada.

Proses kerjanya alat ini adalah berasal dari otak mikrokontroller arduino UNO dan raspberry pi yang bekerja, dimana mikrokontroller ini berfungsi sebagai pengambil keputusan terhadap semua input-input yang telah diberikan dan menggerakkan motor servo, dimana motor servo berfungsi untuk membuka palang pintu otomatis. Sistem dimulai dari penimbangan menggunakan loadcell yang ada terdapat di bawah jembatan penimbangan. Data dari loadcell akan diolah oleh mikrokontroler dengan pemberian info yang dikirim ke RFID sebagai perangkat yang akan discan oleh scanner RFID yang berada pada jembatan timbang[4]. Setelah proses penimbangan data akan diolah oleh mikrokontroler 
yang akan mengirimkan data ke web server stakeholder yang terkait menggunakan Internet of Things (IoT) sehingga tidak akan terjadi pemalusuan data karena data yang diinput tidak dapat diubah.

\section{HASIL DAN PEMBAHASAN}

\subsection{Hasil Perancangan Alat Penimbang Muatan Truk}

Hasil perancangan Alat Penimbang Muatan tuk dibagi menjadi dua bagian, yaitu hasil rancangan perangkat keras (hardware) dan hasil rancangan perangkat lunak (software).

\subsubsection{Hasil Perancangan Perangkat Keras Alat Penimbang Muatan Truk}

Perancangan hardware alat penimbang muatan truk berbasis RFID yang telah berhasil dibuat berdasarkan sketsa rancangan alat. Perangkat keras (Hardware) alat penimbang muatan truk menggunakan sensor load cell yang dapat menimbang muatan truk secara otomatis.

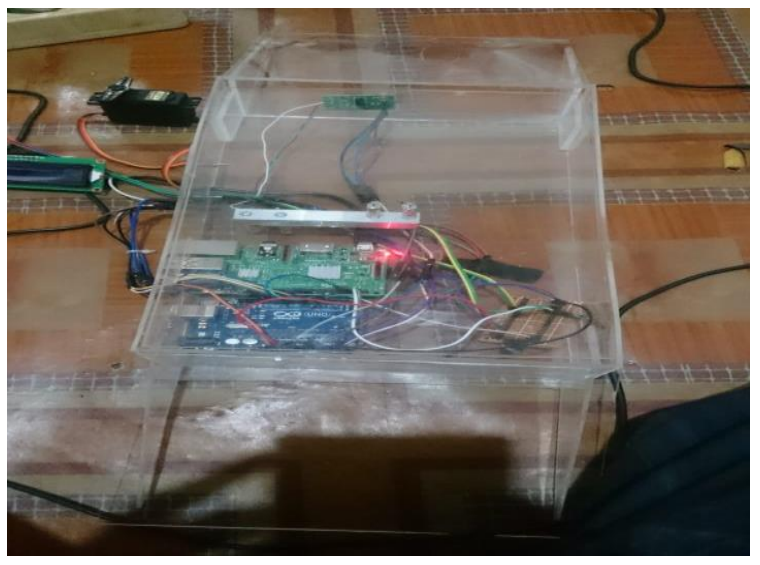

Gambar 2. Tampilan Atas Hardware Alat Penimbang Muatan Truk

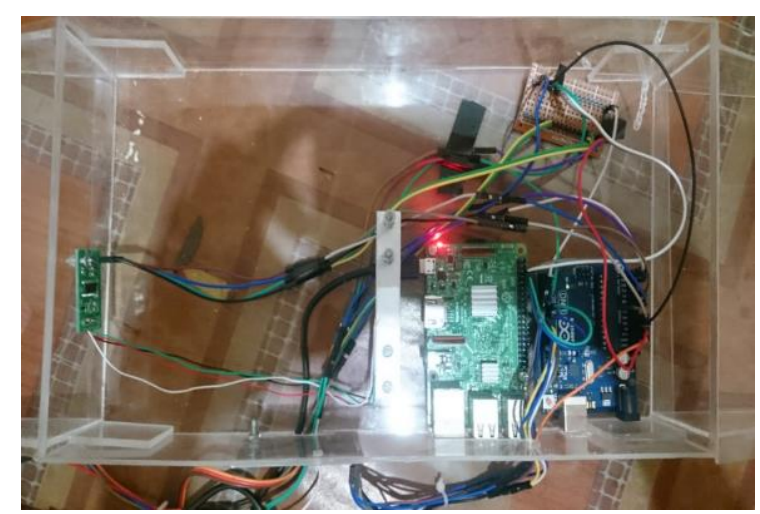

Gambar 4. Tampilan Dalam Hardware Alat Penimbang Muatan Truk

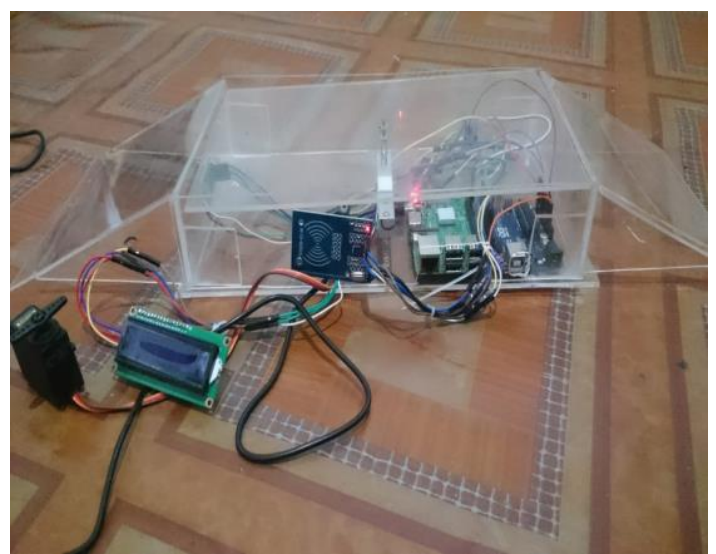

Gambar 3. Tampilan Samping Hardware Alat Penimbang Muatan Truk 
Selain itu hardware penimbang muatan juga dilengkapi dengan RFID yang memiliki 2 fungsi yaitu sebagai scanner dan pembayaran otomatis pada alat penimbang muatan truk. Hardware ini juga dilengkapi dengan motor servo yang berfungsi sebagai palang pintu otomatis, modul arduino uno dan Raspberry Pi.

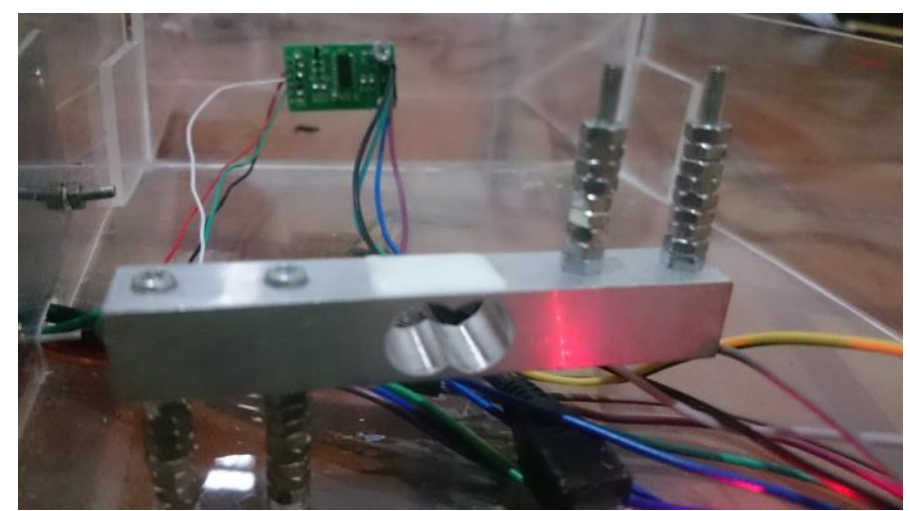

Gambar 5. Sensor Load Cell

Pemasangan sensor load cell pada hardware penimbang muatan truk sangat berpengaruh sehingga bisa menimbang data hasil penimbangan muatan.

\subsubsection{Hasil Perancangan Perangkat Lunak (software)}

Dari pengujian yang telah dilakukan, diperoleh aplikasi berbasis web alat penimbang muatan dengan menggunakan program Putty dan NetBeans. Program telah dapat dijalankan, dan dapat menampilkan hasil data penimbangan muatan truk dengan secara real time.

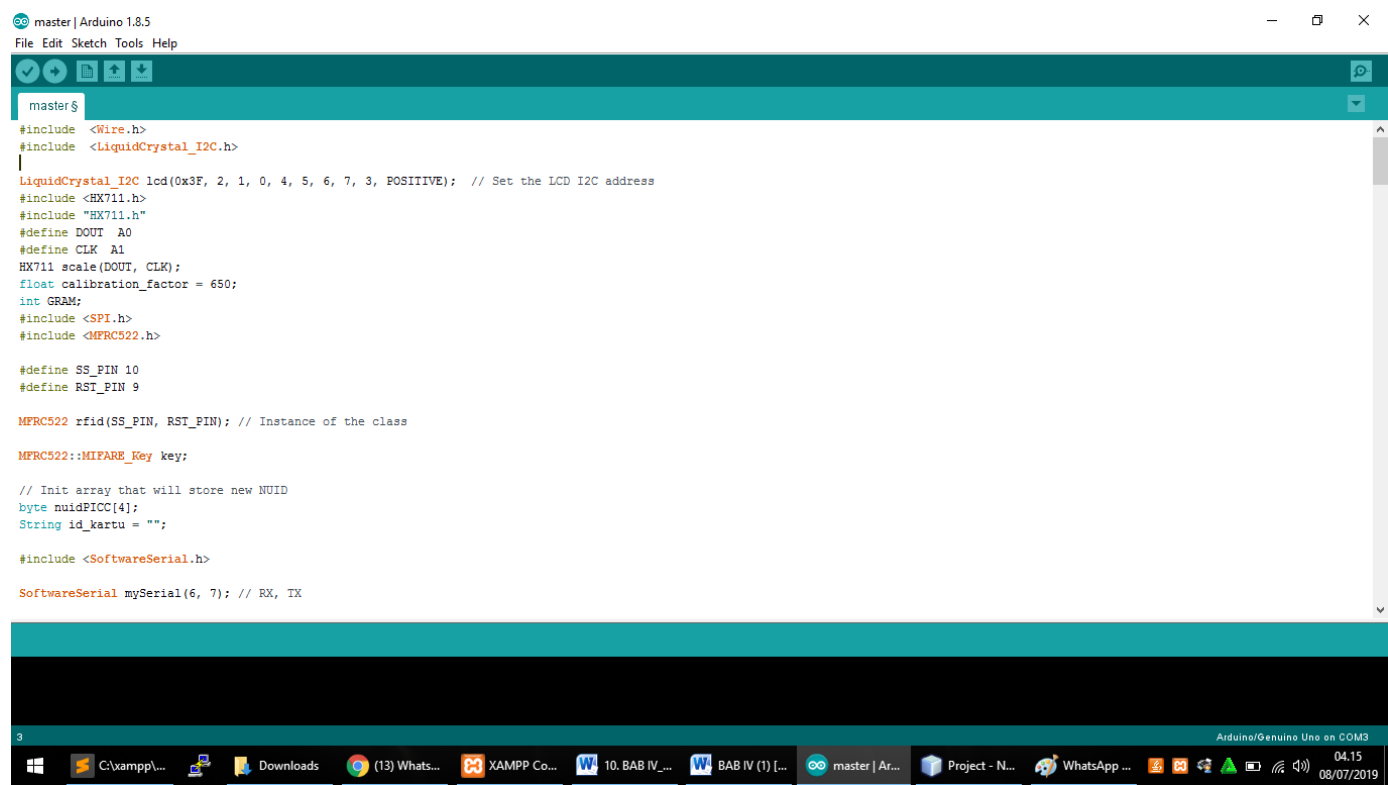

Gambar 6. Source Koding define alat penimbang muatan truk 
Jurnal Riset Sistem Informasi Dan Teknik Informatika (JURASIK)

Volume (4) Juli 2019, pp 142-150

ISSN: 2527-5771/EISSN: 2549-7839

http://tunasbangsa.ac.id/ejurnal/index.php/jurasik

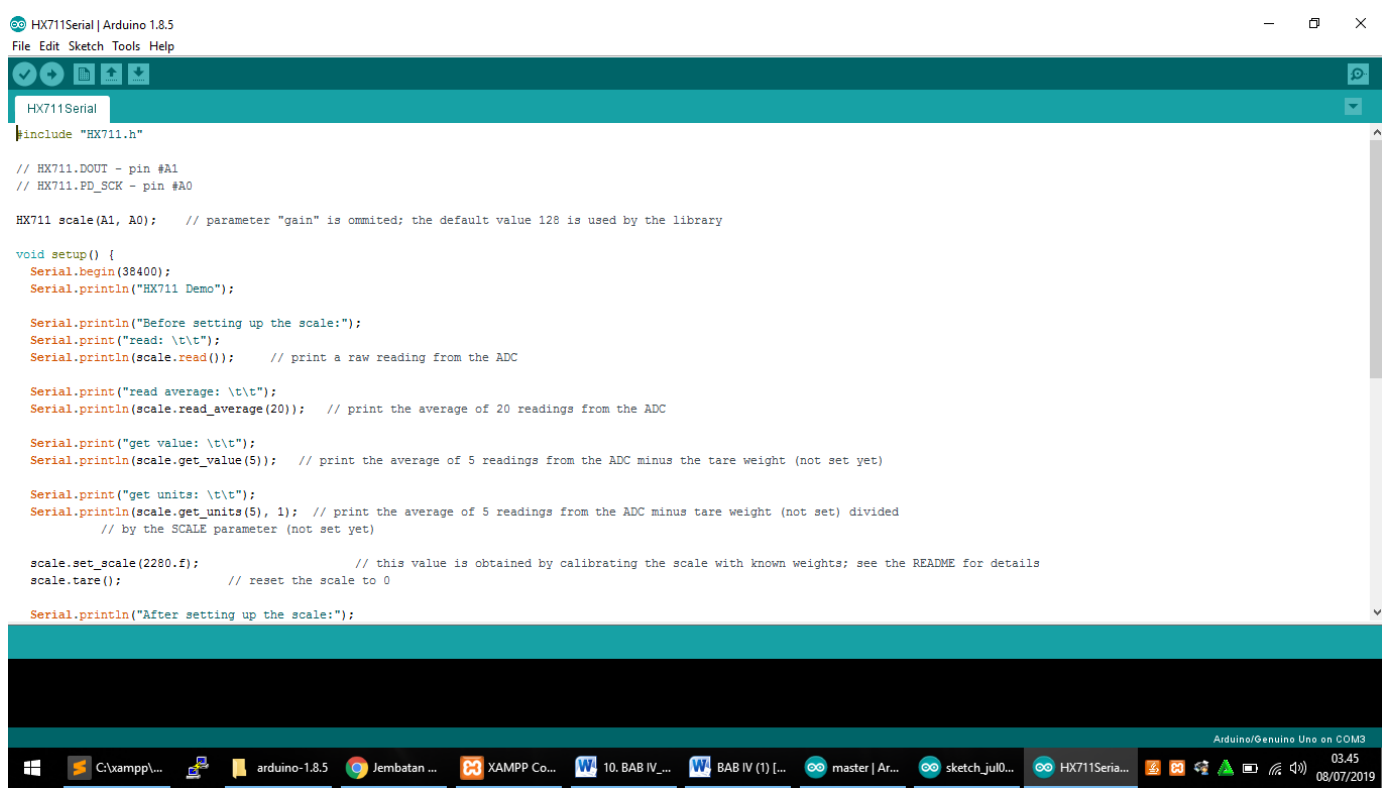

Gambar 7. Source Koding Load Cell

(2) ReadNuID |Arduino 1.8 .5
File Edit Sketch Tools Help

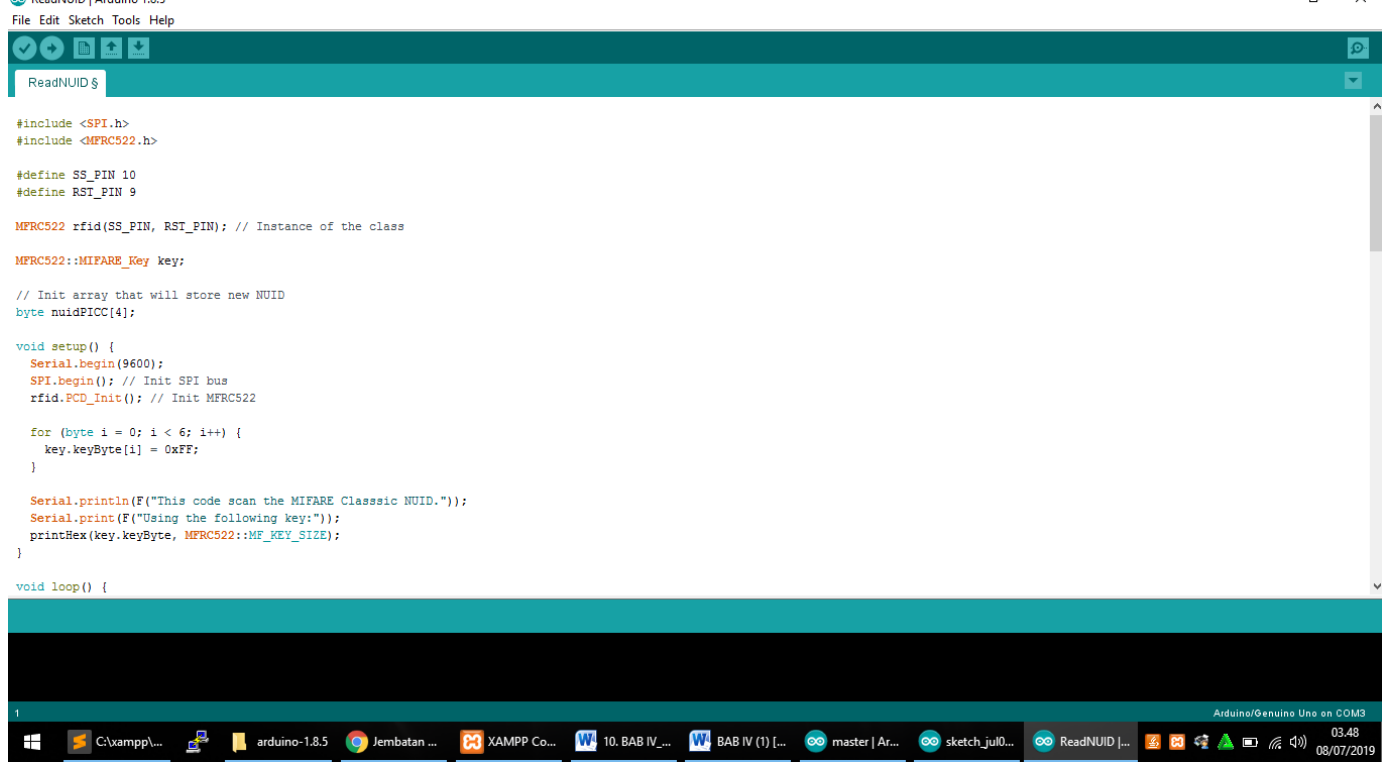

Gambar 8. Source Koding RFID

Gambar diatas menunjukkan potongan dari hasil Source Coding yang digunakan pada Arduino Uno pada alat penimbang muatan truk berbasis RFID. Gambar diatas dapat diartikan sebagai Source Coding awal sebagai Define pada pin-pin yang digunakan pada Arduino Uno, yang akan digunakan sebagai identitas ketika komponen - komponen yang akan dihubungkan dengan Arduino Uno. 


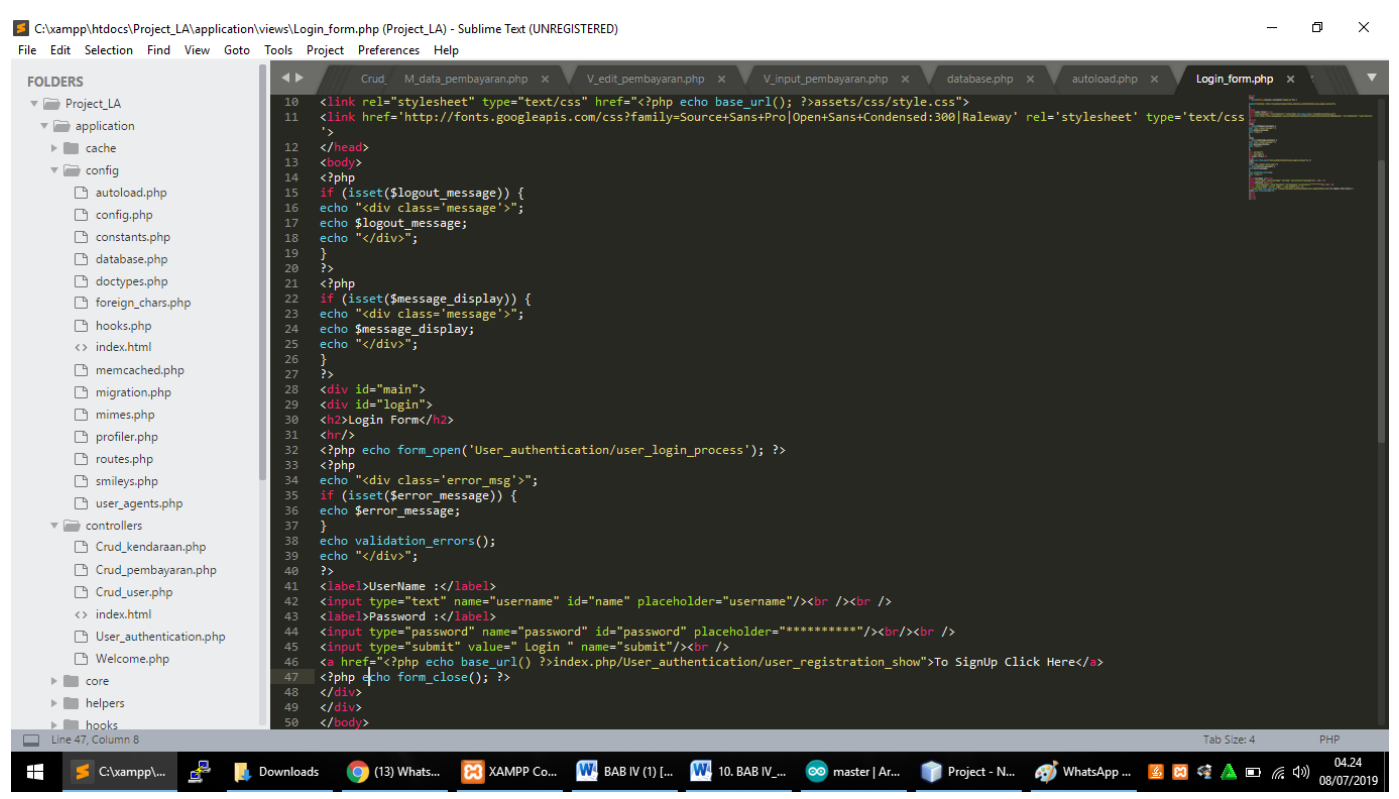

Gambar 9. source koding tampilan menu awal

Pada gambar di atas merupakan source koding yang berfungsi untuk membuat suatu menu. Source koding intent merupakan source koding yang berfungsi untuk mengaktifkan button tadi agar bisa di klik dan bisa berpindah sesuai dengan layout yang kita inginkan.

\subsubsection{Pengambilan Data}

Pada pengujian ini dilakukan pengambilan data sebanyak 3 kali yaitu pada 3 berat muatan yang berbeda pada kartu RFID yang telah diisi saldo. Ketiga berat muatan ini dilakukan pengambilan data dengan berat masing - masing 332 gram, 340 gram, dan 1158 gram dengan biaya yang harus dibayar masing - masing berat berbeda.

Tabel 1. Hasil Penimbangan Muatan Truk

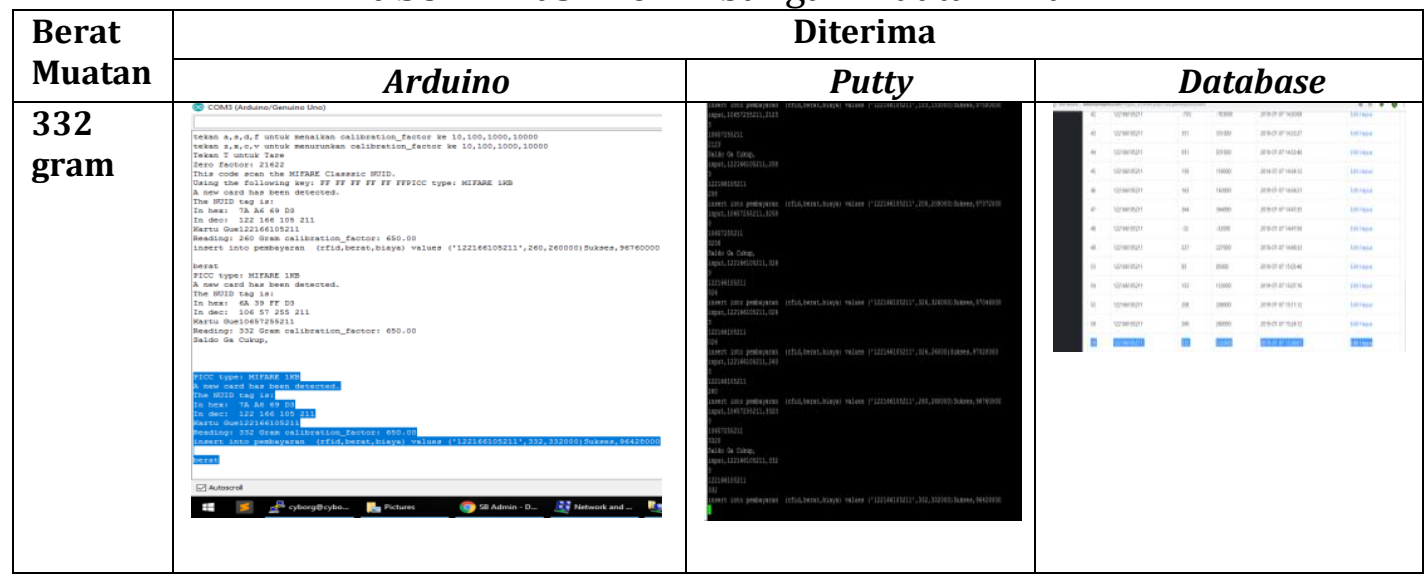




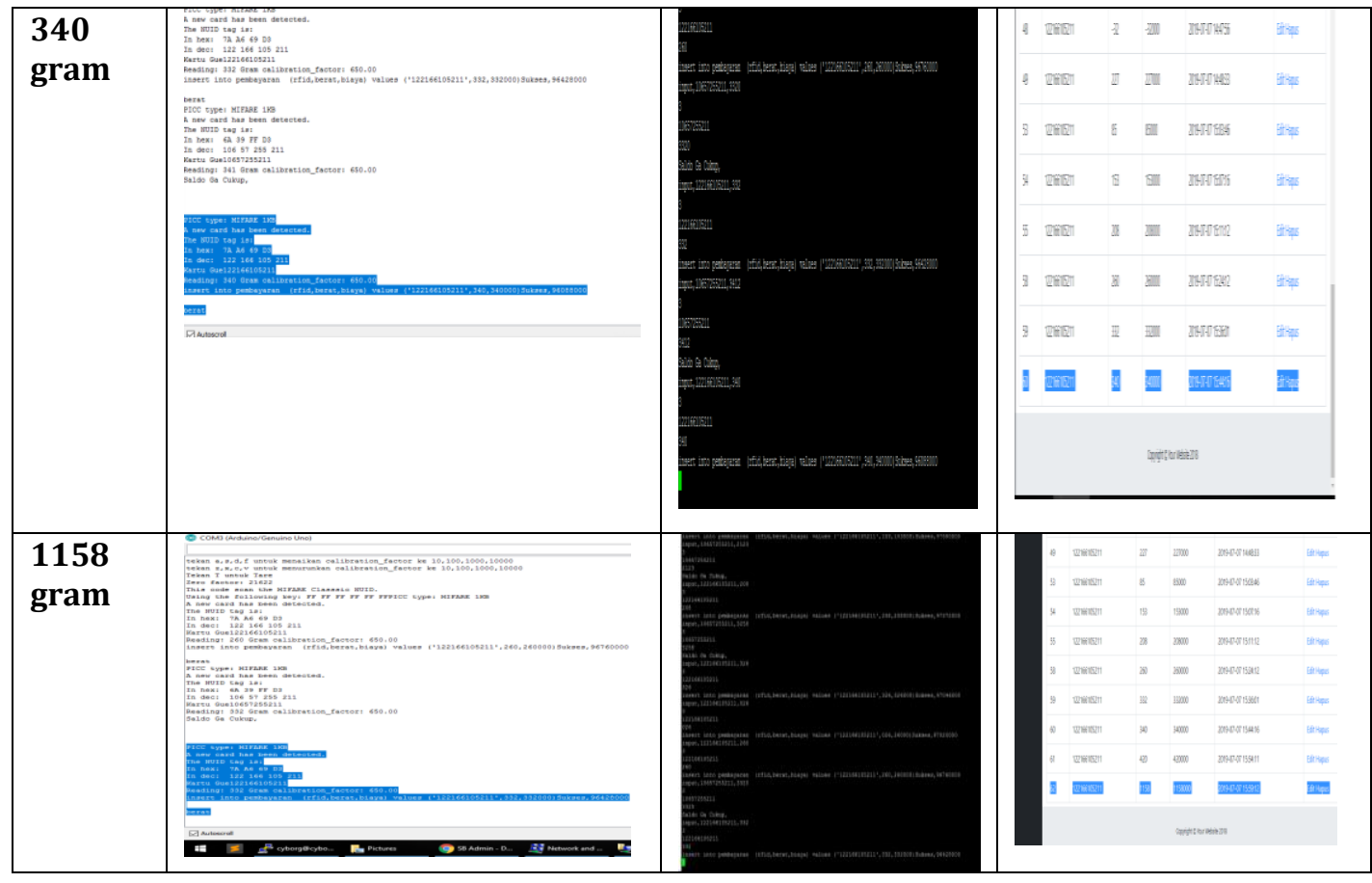

Pada tabel ini mengambil bukti hasil data dari penimbangan yang dihitung di jembatan timbang akan diterima di ketiga software tidak ada perbedaan. Ini dikarenakan sensor load cell ketiga software ini telah sinkron dengan sensor load cell yang sama yang kemudian mengirimkan data berupa berat muatan, dan rfid yang memanca diterima. Notifikasi email dan database tidak terjadi banyak perubahan yang signifikan. Ini dikarenakan kedua notifikasi ini diambil dari satu Kamera yang sama yang kemudian mengirimkan data berupa gambar. Sehingga data yang diterima keduanya juga sama. Kemudian untuk bentuk Notifikasi sms berupa pesan text yang dikirimkan.

\section{SIMPULAN}

Adapun kesimpulan yang dapat dilakukan pada penelitian ini adalah:

a. Perancangan dan pembuatan Implementasi Internet of Things (IoT) Pada Alat Penimbangan Muatan Truk Berbasis RFID

b. RFID sebagai pendeteksi truk dan Sensor Load Cell yang digunakan untuk menghitung berat beban muatan truk serta pengiriman data hasil penimbangan muatan truk menggunakan Internet of Things (IoT).

\section{DAFTAR PUSTAKA}

[1] Gilang Dhimas Yurista Nugraha, "Sistem Identifikasi Beban Angkutan Barang Yang Terintegrasi Pada Jembatan Timbang Menggunakan Kartu Rfid" ,Techno,Vol 18, No. 2, Oktober 2018

[2] Putri Mandarani, " Perancangan Prototype Pengontrolan Jembatan Timbangan Oto Menggunakan Arduino Berbasis Web (Studi Kasus: Unit Pelaksana Penimbangan Kendaraan Bermotor (UPPKB) Lubuak Buayo Kota Padang)", ITP., Padang, 27 Juli 2017 
Jurnal Riset Sistem Informasi Dan Teknik Informatika (JURASIK)

Volume (4) Juli 2019, pp 142-150

ISSN: 2527-5771/EISSN: 2549-7839

http://tunasbangsa.ac.id/ejurnal/index.php/jurasik

[3] Anwar Syarifuddin Fajri, "Sistem Informasi Perparkiran Kendaraan Be4rmotor Roda Dua Di Program Study Sistem Informasi Universitas Jember Menggunakan Rfid" , 2015

[4] Ahmad Arif Ma'rup, "Prototipe Sistem Pengaturan Beban Parkir Mobil Otomatis Menggunakan Protokol Nirkabel Zigbee IEEE 802.15.4" , 2018 